Chapter 4

\title{
Inter- and Intra-Varietal Genetic Variability in Vitis vinifera L.
}

\author{
Stefano Meneghetti, Luigi Bavaresco, \\ Antonio Calò and Angelo Costacurta \\ Additional information is available at the end of the chapter \\ http://dx.doi.org/10.5772/52847
}

\section{Introduction}

Grapevine (Vitis vinifera L.) is the most economically important and widely cultivated fruit crop in the world and it is one of the oldest crops and the only Mediterranean representative of the Vitis genus (Clarke, 2001; Mullins, 1992; Galet, 2000). Its domestication produced cultivars suited to a wide diversity of climates and tastes (Levadoux, 1956; Royo, 1997). In effect this genus shows a wide morphological and genetic variability that is causing confusions and ambiguity for biotypes and clones identification, in particular considering varieties that are widely distributed and cultivated for centuries (Tessier, 1999). Ampelography, ampelometry, and biochemical traits analysis have been traditionally employed to identify the different biotypes in viticulture (Galet, 1979; Calò \& Costacurta, 2004). However, these analyses are based on phenotypic characteristics which can be affected by environmental conditions (Meneghetti, 2011).

The DNA molecular analyses are essential for internationally accepted grapevine identification and the investigation of genetic differences among the Vitis vinifera L. clones (Meneghetti, 2009). Methods based on DNA analysis have been used with varying degrees of success. This might be affected by the variability level of examined grape varieties and by the types of markers systems employed to investigate genetic relationships.

Simple sequence repeat (SSR) markers are universally used for the identification of the grape varieties (This, 2004). Di-nucleotide repeats pose some problems for stuttering, adjacent alleles, and binning and a possible SSR development was proposed by using microsatellites with a longer core repeat (Cipriani, 2010). 
The molecular approaches are also essential for internationally accepted grapevine identification and to investigate the genetic inter- and intra-varietal variability. Molecular markers have been used on Vitis vinifera in several studies to distinguish among clones of the same cultivars as RAPD random amplified polymorphic DNA, PCR specific analysis ISSR (intermicrosatellites), SNP (single nucleotide polymorphism), S-SAP (specific sequence amplified polymorphism), IRAP (inter-retrotransposon amplified polymorphism), REMAP (retrotransposon microsatellite amplified polymorphism), M-SAP (methylsensitive amplified length polymorphism), chloroplast DNA polymorphisms, SSCP (single-strand conformation polymorphism) (Moreno, 1995; Bavaresco, 2000; Imazio, 2002; Owens, 2003; Labra, 2004; D'onofrio, 2009).

A molecular strategy to obtain DNA polymorphisms of Vitis vinifera genotypes from the same cultivar to study the intra- and inter- varietal genetic variability, to discriminate accessions, clones, and biotypes of a same grape variety, and to analyze the relationships between molecular profiles and some environmental parameters (i.e., geographic site) or morphological traits was reported by Meneghetti et al. (2012a; 2012b; 2012c). This approach uses four different molecular marker systems (i.e., AFLP amplified fragment length polymorphism, SAMPL selective amplification of microsatellite polymorphic loci, M-AFLP microsatellites amplified fragment length polymorphism, and ISSR inter simple sequence repeat).

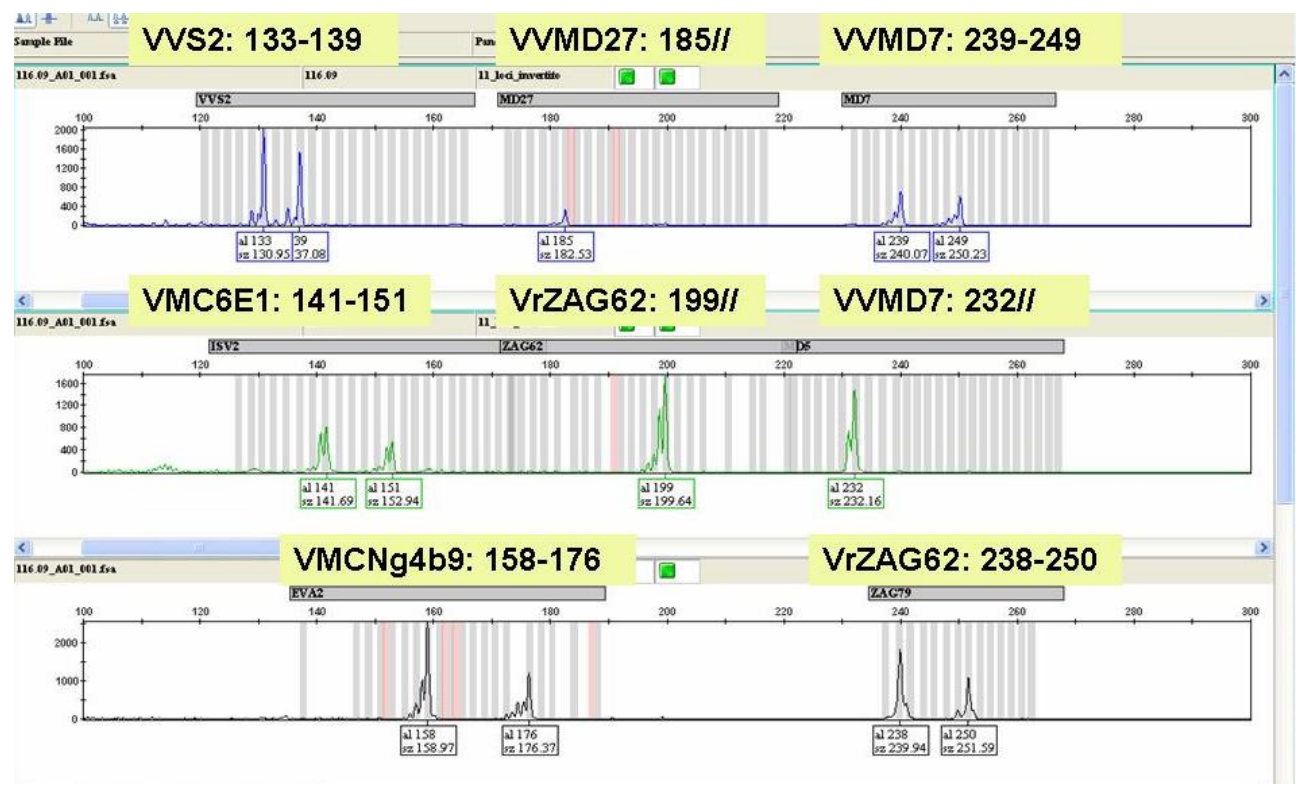

Figure 1. Example of Di-nucleotide SSR profile of Sagrantino cultivar generated by the 3130XL capillary sequencer at eight loci using different fluorochromes. The peaks indicate the alleles and its size on Vitis vinifera SSR BinSet (Meneghetti, 2012c). 


\section{Grapevine cultivar identification}

Simple sequence repeat (SSR) markers are universally used for the identification of the grape varieties (Figure 1). Microsatellites consist of tandemly repeated simple sequence motifs with a high variation in repeat number among individuals. Applications of microsatellite markers include not only cultivar identification but also parentage testing, pedigree reconstruction and studies of population structure.

A strategy of grapevine cultivar identification is to analyze eleven di-nucleotide microsatellite loci as VVS2, VVMD5, VVMD7, VVMD27, VVMD28, VrZAG62, VrZAG79, VMC6E1, VMC6F1, VMC6G1 and VMCNG4b9 (Meneghetti, 2012c). PCR reaction mixture at 11 loci was performed by the workstations using SSR forward labeled primers with 6FAM, VIC, NED and PET dyes, and SSR reverse primers unlabeled each at $5 \mathrm{pmol} / \mu \mathrm{l}$ (Applied Biosystems). The PCR was performed in a GeneAmp PCR System 9700 (Applied Biosystems) and SSR polymorphisms were resolved on an ABI-3130XL capillary sequencer (Applied Biosystems) using GeneMapper version 4.1 (Applied Biosystems) with a Vitis vinifera microsatellite BinSet of 11 SSR standard loci. The important molecular polymorphisms were checked by the Sequi-Gen GT Sequencing Cell electrophoresis (Biorad) (Meneghetti, 2012a).

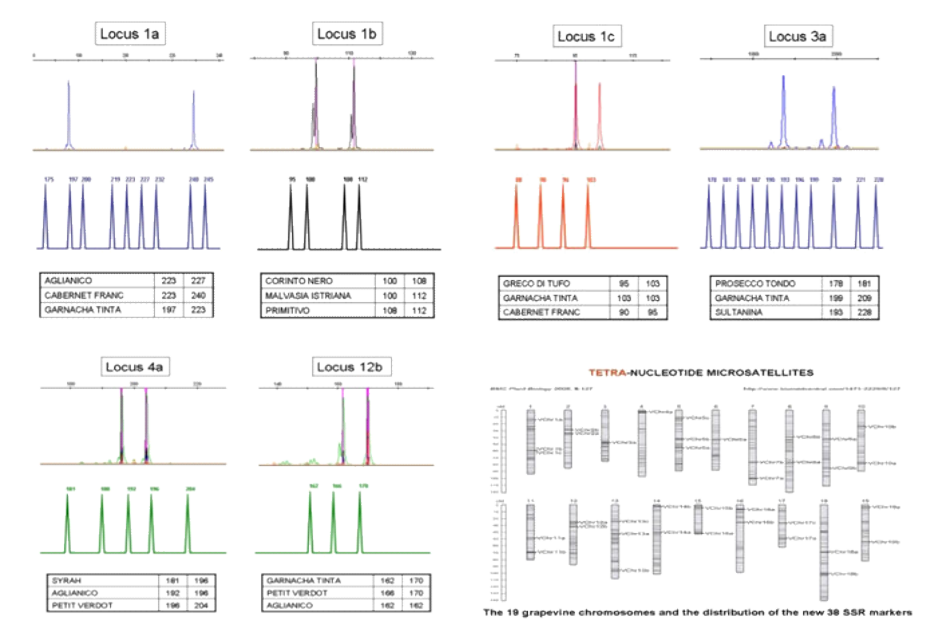

Figure 2. Examples of microsatellites with a longer core repeat in grapevine with the locus name and their position on Vitis vinifera genome (Meneghetti, 2012c).

\section{Inter-varietal genetic variability}

The genus Vitis is characterized by great morphological and genetic variability. It is necessary to increase the number of SSR loci used for cultivars identification to analyze the genetic 
inter-varietal variability by SSR polymorphisms in Vitis. For example: analyzing other microsatellite markers as VVS1, VVS29, VVMD8, VVMD17, VVMD21, VVMD24, VVMD25, VVMD26, VVMD32, VVMD36, VrZAG47, VrZAG64, VrZAG83, VMC6E4, VMC6H6, VMC1E12, VMC4G6, VMC2H9, VMC2A5, VMC3D7, VMC2G2, VMC6E10 (Bowers, 1999). It is also possible to use the microsatellite primers with a longer core repeat (Cipriani, 2010) (Figure 2) or different molecular markers as M-AFLP (Figure 3).

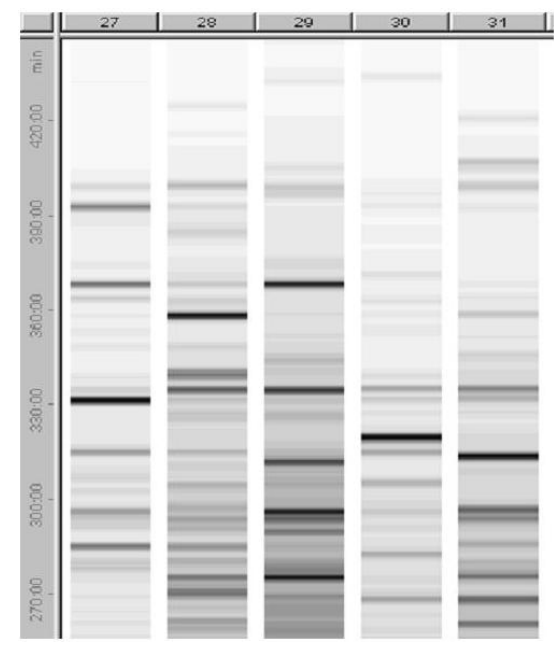

\section{M-AFLP}

27. SCHIAVA GROSSA

28. RABOSO VERONESE

29. PRIMITIVO

30. ALEATICO

31. SANVICETRO

PAD: Eco/Mse

M-AFLP: SSR-Mse+AGT

Figure 3. Examples of molecular polymorphisms of Schiava grossa, Raboso veronese, Primitivo, Aleatico and Sanvicetro grape cultivars by M-AFLP technique.

Genetic dissimilarity of SSR (GD) estimates between grapevine cultivars (inter-varietal genetic variability) were calculated by using the following formula:

$\mathrm{GDij}=-\ln (\mathrm{PS})$

PS is the percentage of common microsatellite alleles within the $\mathrm{i}$ and $\mathrm{j}$ genotypes, according to Dangl (2001).

Dendrogram was produced by the Unweighted Pair-Group Arithmetic Average Method (UPGMA) clustering algorithm and the Numerical Taxonomy and Multivariate Analysis System (NTSYS-pc) Version 2.10 (Exeter Software Co., NY, USA).

In particular for grapevine SSR variability, an additional study was performed by the BAND Genetic Similarity (GS) coefficient of Lynch (1990) used for SSR data in diploid genomes according to the following formula:

$\mathrm{GSij}=\mathrm{Nij} /(\mathrm{Ni}-\mathrm{Nj})$

$\mathrm{Nij}$ is the number of bands in common, $\mathrm{Ni}$ and $\mathrm{Nj}$ are the numbers of bands in the two individuals ( $i$ and $j$ ) being compared. Thus, GSij $=1$ indicates the identity between $i$ and $j$, 
whereas GSij = 0 indicates complete diversity. A pair of diploid individuals can have 0 , 1, or 2 bands in common at each SSR locus. Dendrogram of the analyses were constructed from the symmetrical GS BAND matrix (NTSYS-pc).

An example of these molecular analyses can be explained by the grape Malvasia family. The name Malvasia has ancient origins and refers to a numerous and heterogeneous group of varieties growing in many European countries. Malvasias is spread in Italy from north to south and seventeen Malvasia cultivars are registered in the Italian National Catalogue (Calò \& Costacurta, 2004). There are few Malvasia varieties with black berries, mostly grown in the NorthWestern Italian region of Piedmont (i.e., Malvasia di Casorzo, Malvasia nera lunga and Malvasia di Schierano). Malvasia nera di Brindisi/Lecce contributes to the Salento oenological production in the southern Italian region of Apulia (Lacombe, 2007; Crespan, 2006).

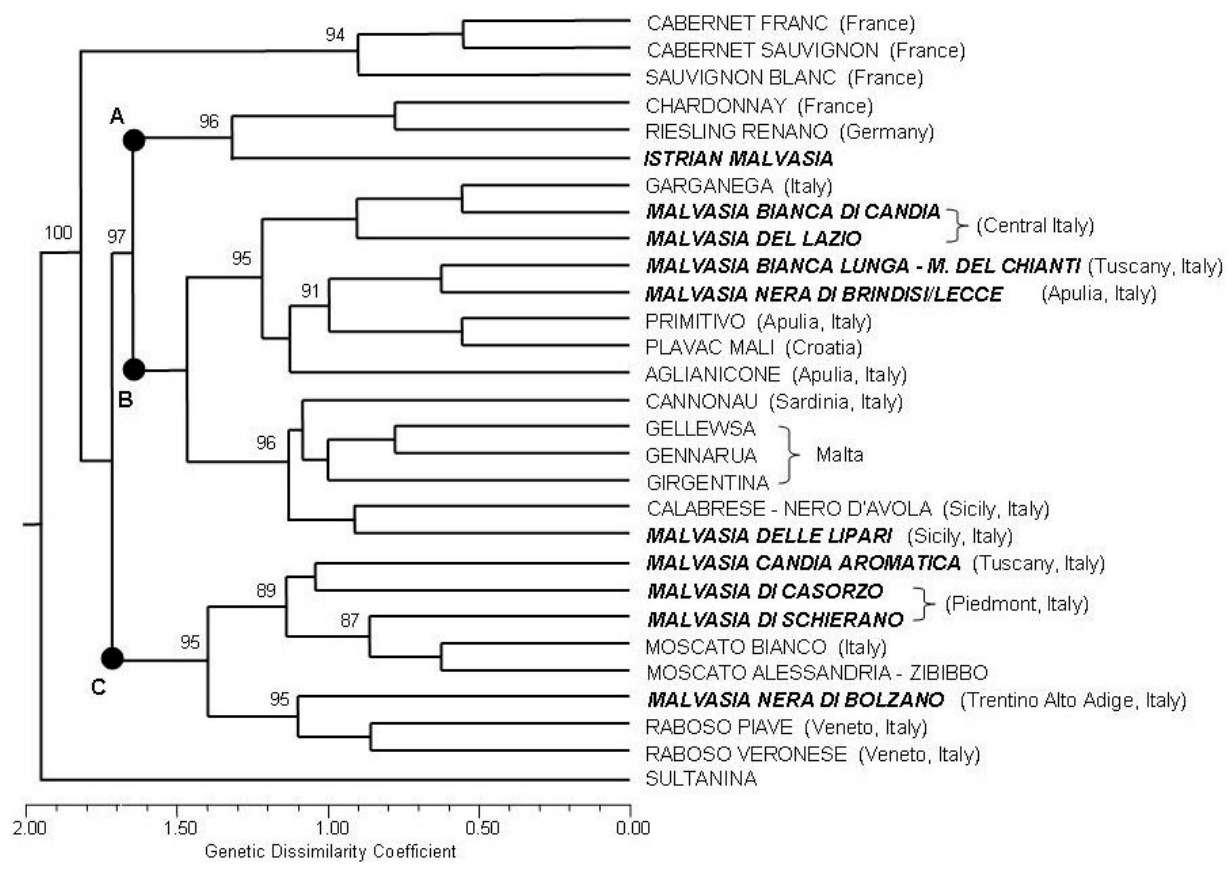

Figure 4. Dendrogram of ten Malvasia cultivars (i.e., Istrian Malvasia, M. delle Lipari, M. bianca di Candia, M. di Candia Aromatica, M. del Lazio, M. Bianca lunga / M. del Chianti, M. nera di Brindisi/Lecce, M. di Casorzo, M. di Schierano, M. nera di Bolzano) and 19 grapevine varieties (i.e., Cabernet Franc, Cabernet Sauvignon, Sauvignon Blanc, Chardonnay, Riesling Renano, Garganega, Primitivo, Plavac Mali, Aglianicone, Cannonau, Gellewsa, Gennarua, Girgentina, Calabrese / Nero d'Avola), Moscato Bianco, Moscato di Alessandria / Zibibbo, Raboso Piave, Raboso Veronese, Sultanina) based on Dangl's Genetic Dissimilarity (Meneghetti, 2012b).

Figure 4 reports a dendrogram of Malvasia cultivars by SSR molecular polymorphisms. The Malvasia cultivars were divided into three distinct groups: Istrian Malvasia was grouped with Riesling Renano and Chardonnay without the other Malvasias (cluster A). Sultanina 
was an out-group. The dendrogram showed clearly the genetic divergence of Malvasias family detected using only the SSR approach, in agreement with Calò and Costacurta 2005. The cluster analysis allowed to distinguish some variety groups cultivated in neighboring geographical regions: Cabernet Franc, Cabernet Sauvignon, Sauvignon Blanc, and Chardonnay from France; Malvasia bianca di Candia and M. del Lazio from Central Italy; Primitivo and Aglianicone from Apulia region (Southern Italy); Nero d'Avola and Malvasia delle Lipari from Sicily region (Southern Italy); Malvasia di Casorzo and M. di Schierano from Piedmont region (Northern Italy); Raboso Piave and R. Veronese from Veneto region (Northern Italy); Gellewsa, Gennarua, and Girgentina from Malta. The Istrian Malvasia was positioned in the A group, while Malvasia bianca di Candia, M. del Lazio, M. Bianca lunga (also known as M. del Chianti), M. nera di Brindisi/Lecce and M. delle Lipari accessions were clustered in the B group and M. di Casorzo, M. di Schierano, and M. nera di Bolzano in the C group.

The ten Malvasias shown in Figure 5 were further analyzed by Genetic Similarity BAND coefficient using the microsatellite polymorphisms. The dendrogram of Malvasias in Fig. 5 showed the grouping of the Malvasia as in dendrogram in Fig. 4. In fact, Malvasia bianca di Candia, M. del Lazio, M. Bianca lunga, M. nera di Brindisi/Lecce, and M. delle Lipari were clustered into B group while M. di Casorzo, M. di Schierano, and M. nera di Bolzano were grouped into the $C$ group, while the Istrian Malvasia is positioned between the two main groups (Meneghetti, 2012b).

\section{Malvasias dendrogram}

GS = BAND coeff., 19 SSR Loci, diploid

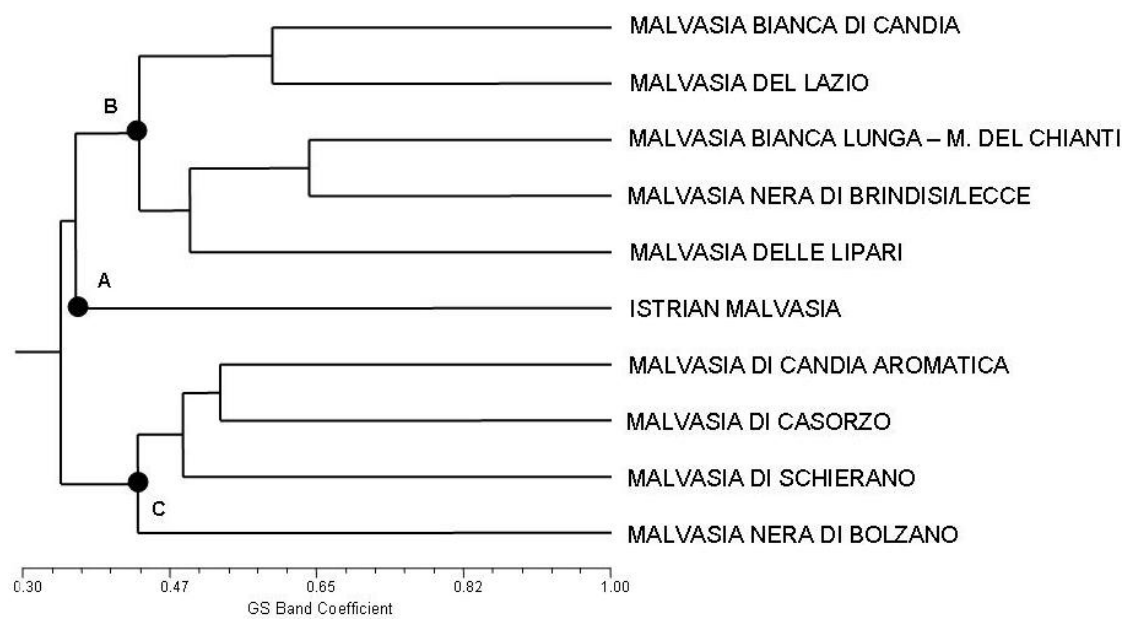

Figure 5. Dendrogram of ten Malvasias cultivars obtained using the Genetic Similarity BAND coefficient. The Genetic Dissimilarity analyses (Fig. 4) were confirmed by this approach and the three subgroups (,$B$ and C) were showed also in this dendrogram with Istrian Malvasia positioned between the two main groups (Meneghetti, 2012b). 


\section{Intra-varietal genetic variability}

The genetic variability of accessions from the same grape cultivar can be investigated by means of AFLP, SAMPL, M-AFLP and ISSR molecular markers according to Meneghetti et al. (2012c).

The AFLP, SAMPL and M-AFLP analyses were performed using a Cy5-labeled EcoRI+3 (or PstI+2) primer and an unlabeled MseI+3 primer (three selective nucleotides). The amplification products were resolved on ReproGel High-Resolution pre-made acrylamide-bisacrylamide solutions ( $8 \% \mathrm{w} / \mathrm{v})$ (GE Healthcare) in modified TBE buffer and detected on a semiautomated DNA sequencer, the ALFexpress-II DNA Analysis System (Amersham Pharmacia Biotech). Markers were visualized automatically by the ALF-win Fragment Analyses 1.09 software and checked by Quantity One 4.6.7 and PD Quest Basic 8.0.1 software (Biorad) (Meneghetti, 2011).

The Inter-microsatellite analysis was performed using the PCR protocol reported by Meneghetti et al. 2012a, with minor changes. ISSR experiment were carried out using the same procedure of AFLP.

A binary presence or absence ( 1 vs. 0 ) matrix was created for AFLP, SAMPL, M-AFLP and ISSR markers and for each grapevine accessions. Molecular markers were defined by a standard ladder using the ALF-win Fragment Analyses 1.09 software (Amersham Pharmacia Biotech) and two reference DNA genotypes and visualized automatically by the ALFwin software. The scoring was checked by using Quantity One 4.6.7 and PD Quest Basic 8.0.1 software (Biorad) (Meneghetti, 2012c).

Genetic similarity (GS) estimates among individuals were calculated in all possible pairwise comparisons using the Dice's coefficient which was based on the probability that a marker from one accession will also be present in another and calculated using the following formula:

$\mathrm{GSij}=2 \mathrm{X} /(2 \mathrm{X}+\mathrm{Y}+\mathrm{Z})$

$X$ represents the number of shared amplification products scored between the pair of samples/fingerprints ( $i$ and $j$ ) considered, $Y$ is the number of products present in $i$ but absent in $j$, $\mathrm{Z}$ is the number of products present in $\mathrm{j}$ but absent in $\mathrm{i}$ (Dice, 1945).

Thus, $\mathrm{GSij}=1$ indicates identity between $\mathrm{i}$ and $\mathrm{j}$, whereas $\mathrm{GSij}=0$ indicates complete diversity.

GS was calculated within $\left(\mathrm{GS}_{\mathrm{W}}\right)$ and between $\left(\mathrm{GS}_{\mathrm{B}}\right)$ cultivars and marker systems (AFLP, SAMPL, M-AFLP).

The cluster analysis of GS was performed according to the UPGMA algorithm using the NTSYS software.

Centroids of the grapevine accessions were plotted on a 2-dimensional graph according to the principal coordinates extracted from the GS matrices estimated by the three molecular 
marker systems. All calculations and analyses were conducted using the appropriate routines of the NTSYS Version 2.10 software.

The information content of each marker system in discriminating the accessions of the same variety was calculated using the marker index (Powell, 1996). The efficiency of dendrograms was tested by cophenetic correlation. The reliability of clusters was evaluated by the bootstrapping procedure using 100 random samples of molecular markers. The software used was PHYLIP 6.6 (http://evolution.genetics.washington.edu/phylip.html).

Hence it was reported and discussed using the molecular results of six grape cultivars (i.e., Garnacha tinta, Primitivo, Malvasia nera di Brindisi/Lecce, Negroamaro, Malvasia di Candia and Istrian Malvasia) on a few different aspects: genetic similarity, genotypes discrimination, biotypes discriminations and clones identification. There were correlations between geographic origins of materials and DNA fingerprinting plus relationships between morphological traits and molecular polymorphisms.

\subsection{Garnacha tinta}

Garnacha is one of the most widely planted grape varieties in the world (240,000 ha). It is known by local names in Mediterranean regions: Garnacha tinta and Grenache noir are the Spanish and French name, while in Italy this variety is known as Cannonao, Alicante, and Tocai rosso (three Italian synonymous) but also as Cannonau (Sardinia) and Gamay perugino (Tuscany) (Galet, 2000; Calò, 1990).

Fifty-three Garnacha accessions were investigated: 28 Italian accessions, 19 Spanish accessions, and 6 French accessions. The Italian accessions were 6 Tocai rosso from the Vicenza area, 8 Alicante from Sicily and Elba island, 4 Gamay perugino from Perugia province and 10 Cannonau from Sardinia. In order to verify the varietal identity, the analyses based on 11 SSR loci confirmed that only one SSR profile was obtained for the 53 accessions (Figure 6) (Meneghetti, 2011).

The study of intra-varietal genetic variability was performed using AFLP, SAMPL and MAFLP molecular markers. The bi-dimensional plotting of centroids reported in Figure 6 showed six different groups: 1) Italian Alicante accessions from Sicily; 2) Italian Tocai rosso accessions from Vicenza area (Colli Berici); 3) Italian Gamay perugino accessions from Tuscany and Umbria; 4) Spanish Garnacha accessions from Andalucia, Aragón, Cataluña, Castilla y León, Madrid; 5) French Grenache noir accessions; 6) Italian Cannonau accessions from Sardinia. The first coordinate allowed to distinguish clearly Spanish, French and Italian accessions while the second one separated the 4 Italian geographic origins (Figure 6).

Genetic similarity of 53 Garnacha samples was calculated within groups $\left(\mathrm{GS}_{\mathrm{W}}\right)$ and also between groups $\left(\mathrm{GS}_{\mathrm{B}}\right)$ (Meneghetti et al. 2012c). The PCA analysis confirmed the high genetic variability within Italian genotypes on the base of their provenance, on the contrary the 19 Spanish accessions were clustered in a more homogeneous group that showed a high genetic similarity $\left(\mathrm{GS}_{\mathrm{W}}=0.9872\right)$. 


\section{CENTROIDS}

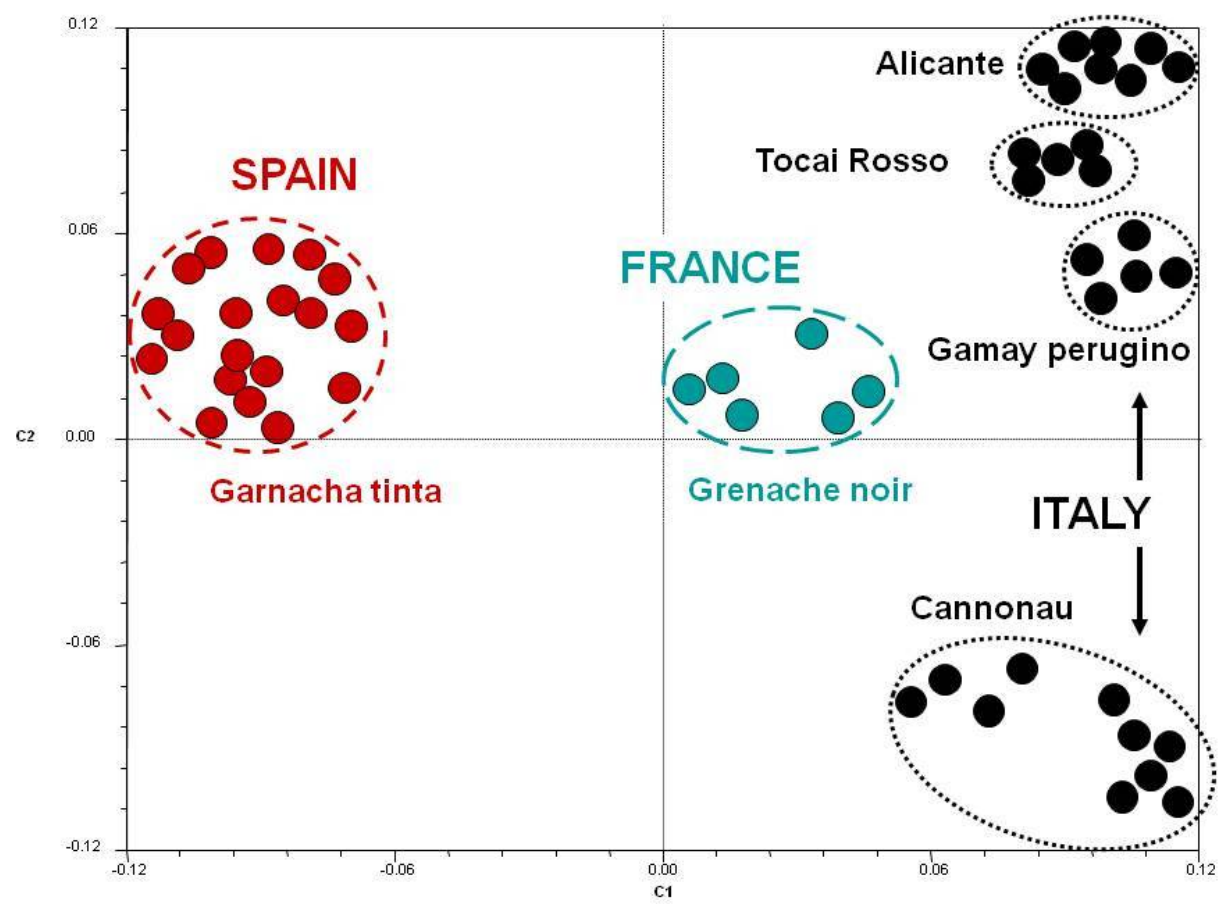

Figure 6. Centroids of Garnacha tinta from Spain, Grenache noir from France, Alicante from Sicily (Italy), Tocai rosso from Vicenza area (Italy), Gamay perugino from Tuscany (Italy), Cannonao from Sardinia (Italy). The Genetic Similarity analyses were confirmed by this approach and the materials with same SSR profile were distinct according to the six geographic origins and the three Countries (Meneghetti, 2011).

The molecular approach discriminates all genotypes of this cultivar. Italian samples showed a high genetic variability within genotypes $\left(\mathrm{GS}_{\mathrm{W}}=0.9481\right)$, while Spanish samples showed a high GS $\left(\mathrm{GS}_{\mathrm{W}}=0.9872\right)$. $G S_{\mathrm{W}}$ of Italian accessions $(0.9481)$ was very similar to $\mathrm{GS}_{\mathrm{B}}(0.9480)$, but the four Italian origins are clearly separated by these molecular markers (Meneghetti, 2011).

AFLP, SAMPL, and M-AFLP were able to clearly distinguish the 53 Garnacha accessions from Italy, Spain, and France. The large number of molecular markers and their high degree of polymorphism make them important tools for many genetic studies.

Provenance-specific molecular polymorphisms were reported in Figure 7 and AFLP analyses shown in Figure 8. 


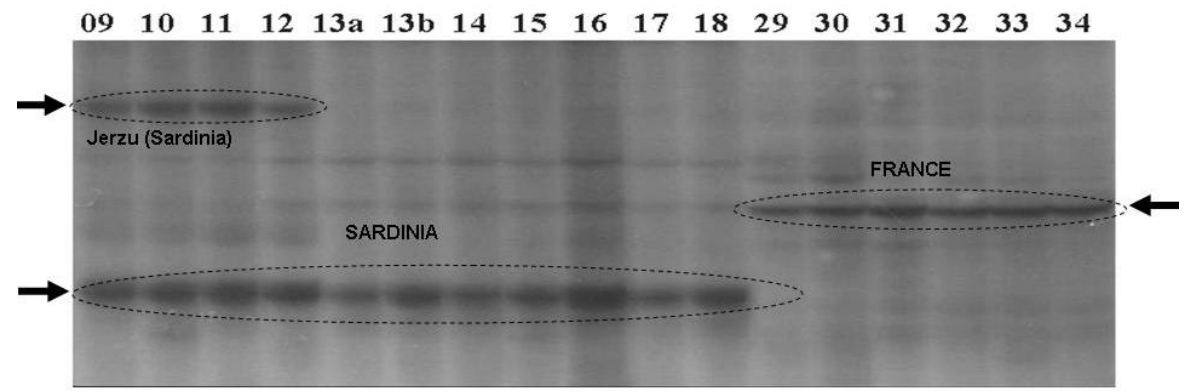

Figure 7. Provenance-specific polymorphisms by SAMPL molecular markers obtained for the 10 Sardinian Cannonau (CAN-09/18) and six French Grenache (GRE-30/34) using Silver Staining technique. The first four line (09-12) corresponding to Cannonau from Jerzu (CAN-09/12) with a specific amplification product (Meneghetti, 2011).

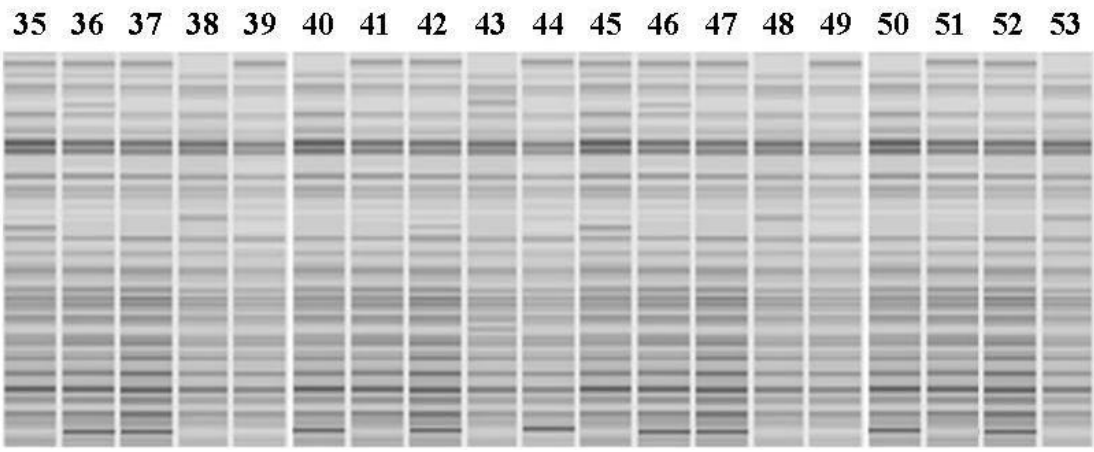

Figure 8. An example of a digitalized electropherogram of the AFLP profiles obtained for the 19 Spain Garnacha accessions (GAR-35/53) using an ALFexpress-II DNA Automated Sequencer. The majority of AFLP markers were monomorphic but there were some clearly differences: the line 36 and 46 are very similar (two G. blanca genotypes) and line 37 and 49 showed only a different marker (two G. peluda genotypes). Genotypes from left to right: 35= Garnacha tinta, 36= G. blanca, 37= G. peluda, 38= G. roja; from 39 to 45= Garnacha tinta; $46=\mathrm{G}$. blanca, 47= G. erguida, 48= G. roya, $49=\mathrm{G}$. peluda; from 50 to $53=\mathrm{G}$. tinta (Meneghetti, 2011).

\subsection{Primitivo}

Primitivo is a grapevine variety very important for Apulian viticulture and according to tradition it was first planted by Benedictine monks in Gioia del Colle (Bari, Apulia, Italy). Primitivo di Gioia is the best known variety used in Gioia del Colle DOC wine and is genetically equivalent to the Croatian Crljenak Kaštelanski and the American Zinfandel (Calò \& Costacurta, 2004; Calò, 2008).

Fifty-nine different vines have been selected based on discriminating traits (i.e., shape, size, density, color of the skin of the bunch and of the berry). Five typologies called A, B, C, D, and $\mathrm{E}$ have been identified by means of ampelographic and phyllometric analyses. The morphological traits of the five biotypes (i.e., leaves, bunch, and berry) were maintained after 
repeated propagation of these biotypes in experimental vineyards. Thus, the morphological traits could have been fixed and stabilized during several centuries of cultivation at Gioia del Colle (Meneghetti, 2012a).

The identical SSR profiles of Primitivo biotypes are shown by a Reference Primitivo clone from Taranto (Apulia, Italy) and two Zinfandel accessions from USA.

Dice's GS matrix was used to perform the Principal Coordinate Analysis of all Primitivo accessions.

Molecular markers discriminated the five biotypes from Gioia del Colle (Bari, Italy) to those From Pulsano (Taranto, Italy) and Zinfandel accessions from USA (Figure 9).
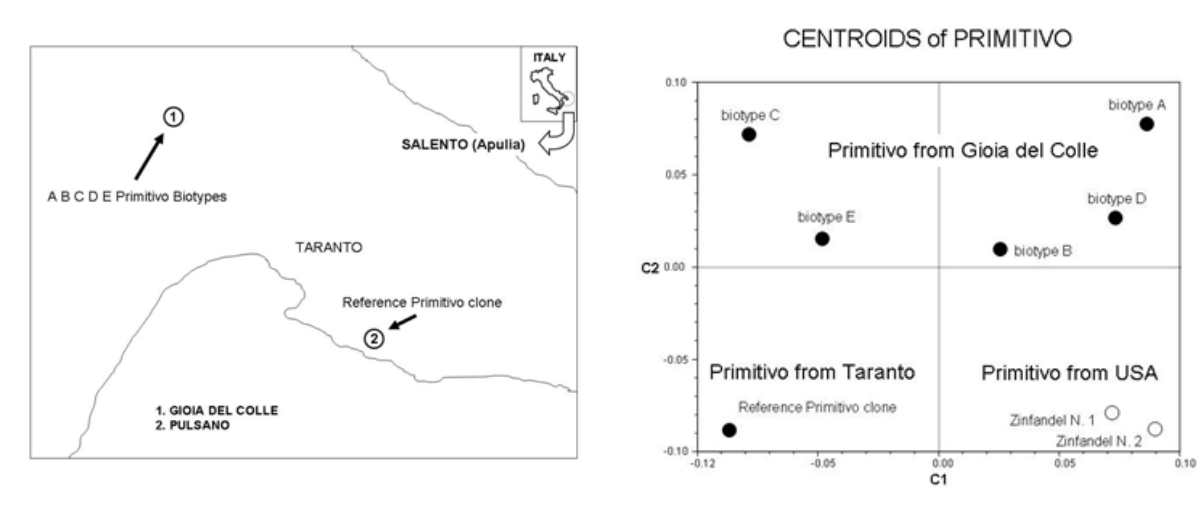

Figure 9. Geographic map of the five Primitivo biotypes from Gioia del Colle (Apulia, Italy) and the reference clone from Pulsano (TA). Centroids discriminated the genotypes according to the different geographic origins (i.e., Gioia, Pulsano, USA) (Meneghetti 2012a).

A total of 2,223 reproducible amplification products were obtained using four molecular marker systems (i.e., 837 AFLPs, 713 SAMPLs, 616 M-AFLPs and 57 ISSRs) and 1,156 products $(52.0 \%)$ were polymorphics.

The molecular analysis displays a high genetic variability within Primitivo genotypes which is in agreement with the non-homogenous geographical areas of cultivation. The GS was 0.8129 among Primitivo biotypes from Gioia del Colle; the GSw was 0.9477 within American accessions; the $\mathrm{GS}_{\mathrm{B}}$ was 0.7489 between Gioia del Colle biotypes and the Reference clone from Pulsano and the $\mathrm{GS}_{\mathrm{B}}$ was 0.7013 between the five Apulian biotypes and the two Zinfandel accessions from USA.

Dice's GS matrix was used to perform the Principal Coordinate Analysis using all Primitivo accessions (Figure 9).

The molecular markers discriminated the Gioia del Colle biotypes from the Pulsano Reference biotype and to the two American Zinfandel accessions (Figure 9). 
The first coordinate of the centroids allowed to distinguish the five different biotypes of Gioia del Colle. The second coordinate allowed to separate the biotypes of Gioia del Colle from the two American Zinfandel accessions and the Primitivo reference clone of Pulsano (Figure 9).

Thus, we could discriminate both the Primitivo accessions (i.e., the 5 biotypes from Gioia del Colle, the clone from Pulsano, the two American Zinfandel accessions) and the different geographical origins of the plants.

\subsection{Malvasia nera di Brindisi/Lecce}

Malvasias belong to a numerous and heterogeneous population of varieties growing in many European countries and their history is an intriguing enigma. Several types of grape varieties have been traditionally considered under the generic term of Malvasia, often with a complementing name related to geographic origin (Crespan, 2008; Calò \& Costacurta, 2004).

In Italy, at the present time, Malvasias are spread from North to South and 17 Malvasia cultivars are registered in the Italian National Catalogue. Apulian Malvasia nera is a cultivar with black berries and belongs to the Apulian ampelographic assortment: this grape is very widespread in the Salento peninsula, from the Taranto area right across to the provinces of Brindisi and Lecce.

The Malvasia nera of Lecce and Brindisi, originated from the cross between Malvasia bianca lunga or Malvasia del Chianti and Negroamaro. It represents an important variety in the Apulia region. In the past, Malvasia nera of Brindisi and Malvasia nera of Lecce were considered two different cultivars, but this presumed synonymy has been ascertained with SSR markers and therefore these two Malvasia nera would be considered to be the same variety (Meneghetti, 2012a). Morphological analysis allows to differentiate accessions of this cultivar when we compare biotypes cultivated from the Lecce region with others from the Brindisi region. For this reason deeper molecular analyses have been conducted to investigate differential molecular traits between these two Malvasia cultivars with different geographical origin.

Thirteen accessions of Italian Malvasia nera from Brindisi (Salento, Apulia) and thirteen accessions of Italian Malvasia nera from Lecce (Salento, Apulia) were analyzed. All the accessions show the same SSR profile and were identified as Malvasia nera of Lecce and Brindisi. AFLP, SAMPL, M-AFLP and ISSR analyses were performed in order to study the intra-varietal variability.

A total of 2,049 reproducible amplification products were obtained with the four molecular marker systems, 756 AFLPs, 615 SAMPLs, 626 M-AFLPs and 52 ISSRs.

The discrimination among the 26 genotypes of Malvasia nera of Lecce and Brindisi from the two different geographic origins of Salento (Lecce and Brindisi) was possible using the four marker types as reported in Figure 10 where as MLB is Malvasia nera of Lecce and Brindisi.

The MLB genotypes with the numbers 1 to 13 were from Brindisi while samples with the numbers 14 to 26 were from Lecce. 

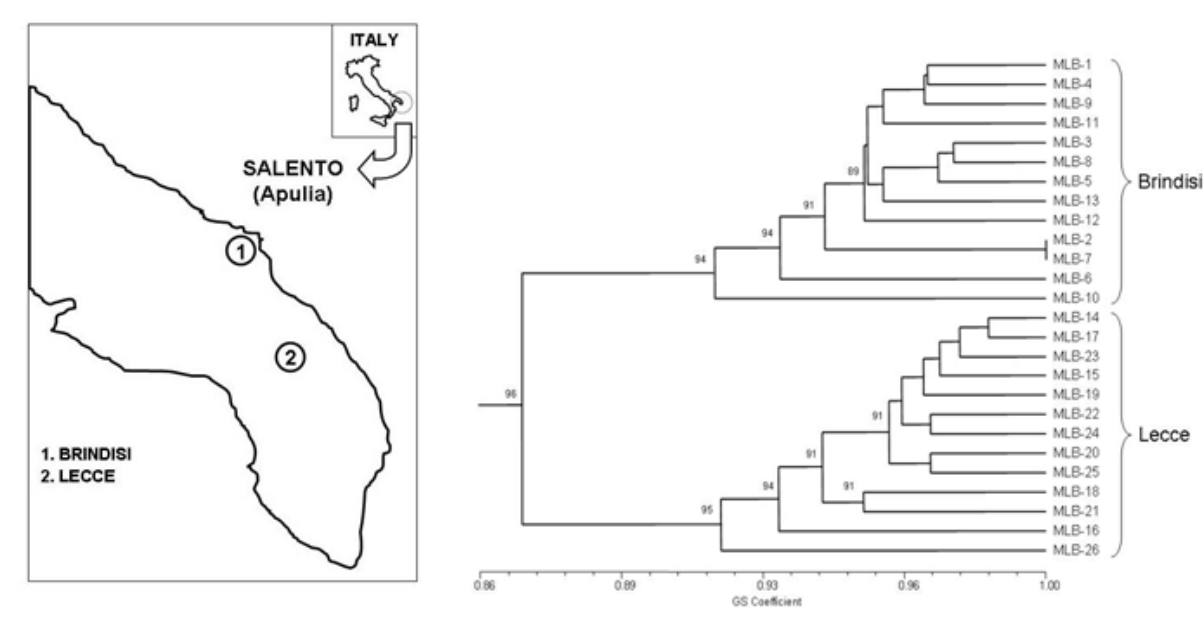

Figure 10. Geographic map of Lecce and Brindisi (Apulia, Italy) and dendrogram of genotypes of Malvasia nera di Brindisi/Lecce from Lecce and from Brindisi regions (Meneghetti, 2012a).

The cluster analysis clearly grouped the 26 accessions according to the two geographical origins, Lecce and Brindisi. Two accessions from Brindisi (number 2 and 7) showed the same molecular profile (i.e., identical genotype).

Genetic similarity (Dice, 1945) estimated within and between the two origins, Brindisi and Lecce, was confirmed that these two groups were not genetically identical. The $\mathrm{GS}_{\text {Tот }}$ was 0.8269 , the $\mathrm{GS}_{\mathrm{W}}$ within the 13 accessions from Brindisi was 0.9544 and the $\mathrm{GS}_{\mathrm{W}}$ relating of the 13 accessions from Lecce was $0.9589 ; \mathrm{GS}_{\mathrm{B}}$ between the two origins was 0.7572 .

The molecular approach was efficient to discriminate the Apulian Malvasia nera accessions from these two different provinces of the Salento area.

\subsection{Negroamaro}

Negroamaro is a grape variety native to Southern Italy and is grown almost exclusively in Apulia (Calò \& Costacurta, 2004).

This grapevine cultivar is considered to have an even older origins in Apulia (i.e., possibly brought by ancient Greek settlers that colonized Southern Italy) and it is one of the most important popular wine varieties of the Salento area.

This variety produces the famous regional red and rosé wines 'Negroamaro Cannellino' that comes from a distinct biotype which is listed separately in the Italian Register of Grapevine Cultivar (Calò, 2000). Although the SSR markers don't distinguish it from the Negroamaro variety, the somatic mutation that allows a characteristic precocity of maturation (15 days) of 'Negroamaro Cannellino' affects a fundamental physiological distinctive trait. Therefore, 
it is not possible to consider these two Negroamaro biotypes from the same cultivar (Meneghetti, 2012a).

Forty-four accessions of Negroamaro from Apulia (Italy) analyzed at 11 microsatellite loci showed a microsatellite profile in agreement with the Negroamaro grapevine variety.

In order to define the intravarietal variability AFLP-based molecular markers and inter-microsatellites were used.

The Negroamaro accessions were from eight different geographic origins of Salento (Apulia, Italy): Alezio, Tuglie, Copertino, Veglie, Leverano, San Pancrazio, Cellino San Marco and Ceglie Messapica.

A total of 2,282 reproducible amplification products were obtained with the four molecular marker systems, 856 AFLPs, 756 SAMPLs, 620 M-AFLPs and 50 ISSR and 1,022 (44.8\%) of these were polymorphics.

The Negroamaro accessions were separated according to their specific origins and according to a gradient "lowland-hill" or "North-South Apulia" as shown in Figure 11. The Negramaro accession from the Northern hilly origin, Ceglie Messapica, is shown as an outgroup.
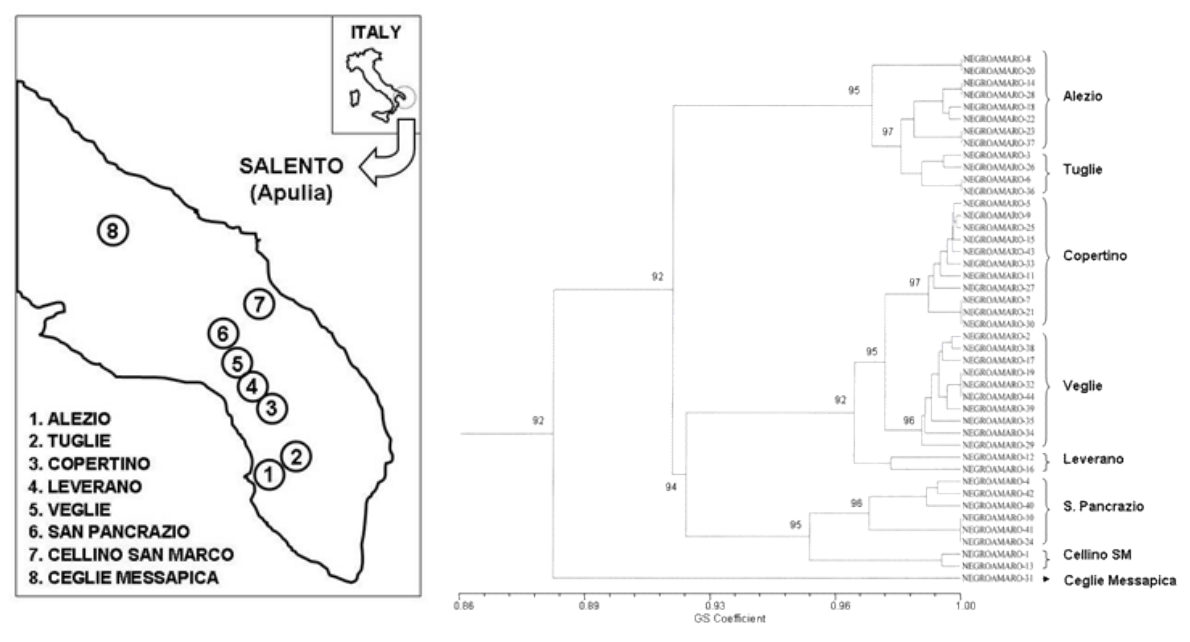

Figure 11. Geographic map of the 8 Negroamaro origins (Apulia, Italy) and Dendrogram of genotypes of Negroamaro from the different Salento areas (Meneghetti, 2012a). 
The genetic variability among the Negroamaro materials showed an high correlation between the geographic origins (environmental variability) and the molecular profiles; this is important for the choice of the Negroamaro clones to be propagated in the Salento area.

\subsection{Malvasia di Candia}

The white Malvasia di Candia SS (i.e., Simple Savor, not aromatic) is a cultivar of the great and heterogeneous Malvasia family and represents one of the principal varieties of the Frascati DOC area. It is also known as 'Red Malvasia' due to the red shoots color (Calò \& Costacurta, 2004).

Many biotypes of Malvasia di Candia with large sized berry bunches are present in the Frascati area after 1950. Thirty accessions of this cultivar were selected from 150 old vineyards from this area in an earlier study. Morphological and molecular analyses were performed to indentify the most interesting biotypes which revealed a large variability at morphological and molecular levels. The 30 accessions were identified as white Malvasia of Candia (SS) by SSR markers.

Ampelography and ampelometry analyses clustered four biotypes called AA, A, B, and AB (Figure 12).

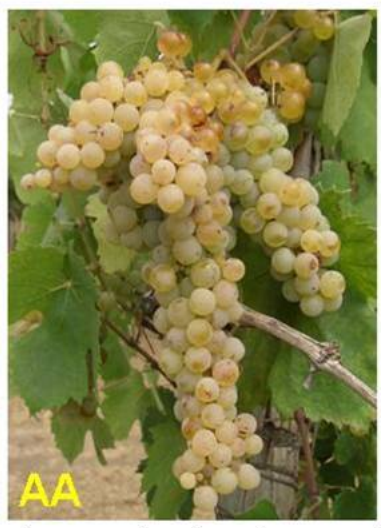

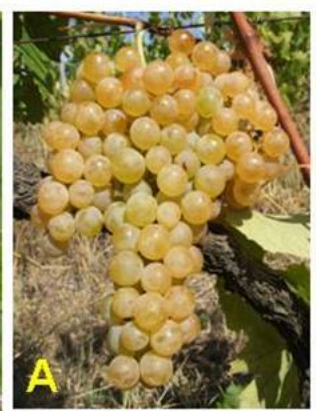

Biotype A: bunch similar to biotype AA with small dimension and less evident wings

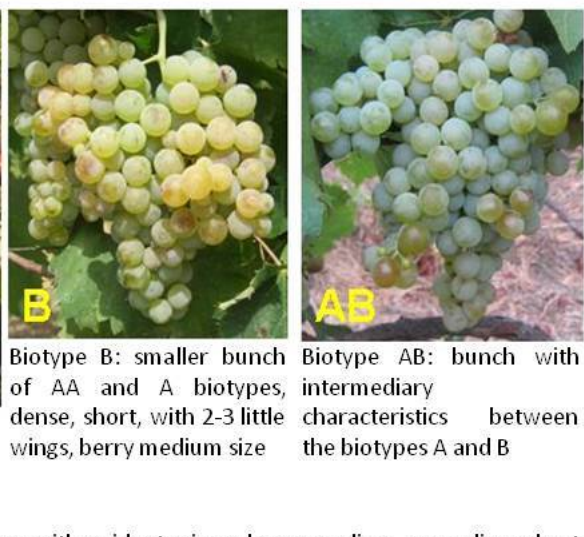

Biotype AA: bunch medium or medium-wide, long, medium-dense with evident wings; berry medium or medium-short irregular size

Figure 12. Bunches of the four biotypes of Malvasia di Candia (Meneghetti, 2012c).

Biotype AA shows medium sized, long bunches with evident wings; medium irregular berry size (Figure 12). Biotype A was similar to biotype AA with smaller sized bunches and wings. Biotypes B has smaller, shorter, less compact bunches than biotypes AA and A. Biotype $\mathrm{AB}$ showed bunch with intermediary characteristics between biotypes A and B. AFLP, M-AFLP, and SAMPL molecular markers were used to analyze the intra-varietal genetic variability (Meneghetti, 2012a). 


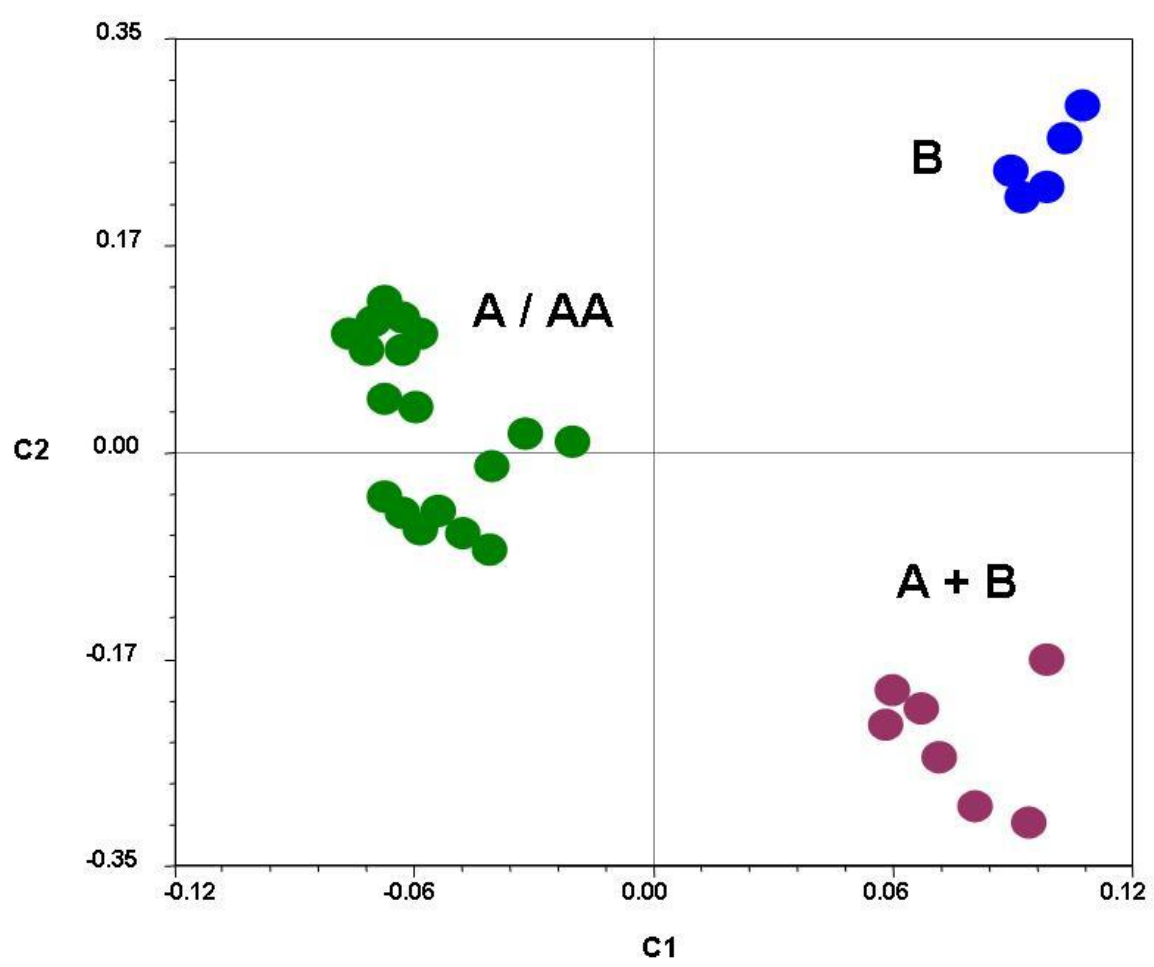

Figure 13. Centroids of Malvasia di Candia accessions that discriminated the 30 genotypes according to the different morphological traits of bunches (i.e., $A, A A, B, A B$ ).

Cluster analyses showed a correlation between molecular profile and morphological traits of bunches relating to Malvasia di Candia biotypes (Figure 13).

Biotypes B (smaller fruit size) were clearly discriminated from the remaining typologies (larger fruit size) even if the accessions with $\mathrm{A}$ and AA bunch types were grouped in the same cluster (A/AA) (Figure 13).

\subsection{Istrian Malvasia}

Istrian Malvasia is a cultivar from Northern Italy and the Istrian Peninsula (Calò \& Costacurta, 2004; Crespan, 2006). It is known in Croatia as Malvazija istarska (Crespan, 2008). This cultivar is the most commercially important and widely cultivated grapevine variety in Istria (Croatia).

Several biotypes of this grapevine cultivar were selected in Italy during clonal selections by research institutes.

A study was carried out on 30 Istrian Malvasia genotypes consisting of eight Italian clones (i.e., ISV 1, ISV F6, VCR 4, VCR 113, VCR 114, VCR 115, ERSA 120, ERSA 121) and 22 au- 
tochthonous grapevine accessions grown in Istrian Peninsula (Croatia); the morphological and genetic intra-varietal variability of this cultivar was evaluated.

Ampelographic characterizations of accessions were performed using 20 OIV descriptors relative to young shoot, shoot, young leaf, mature leaf, inflorescence, bunch and berry (2nd edition of the OIV descriptor list for grape varieties and Vitis species). Dendrogram based on morphological data was performed using the absolute mean distances (Manhattan - City Block) and the Complete Linkage (Fabbris, 1997).

The microsatellite analyses confirmed the varietal identity of the 30 genotypes analyzed. SSR profile of Istrian Malvasia was reported in Figure 14.

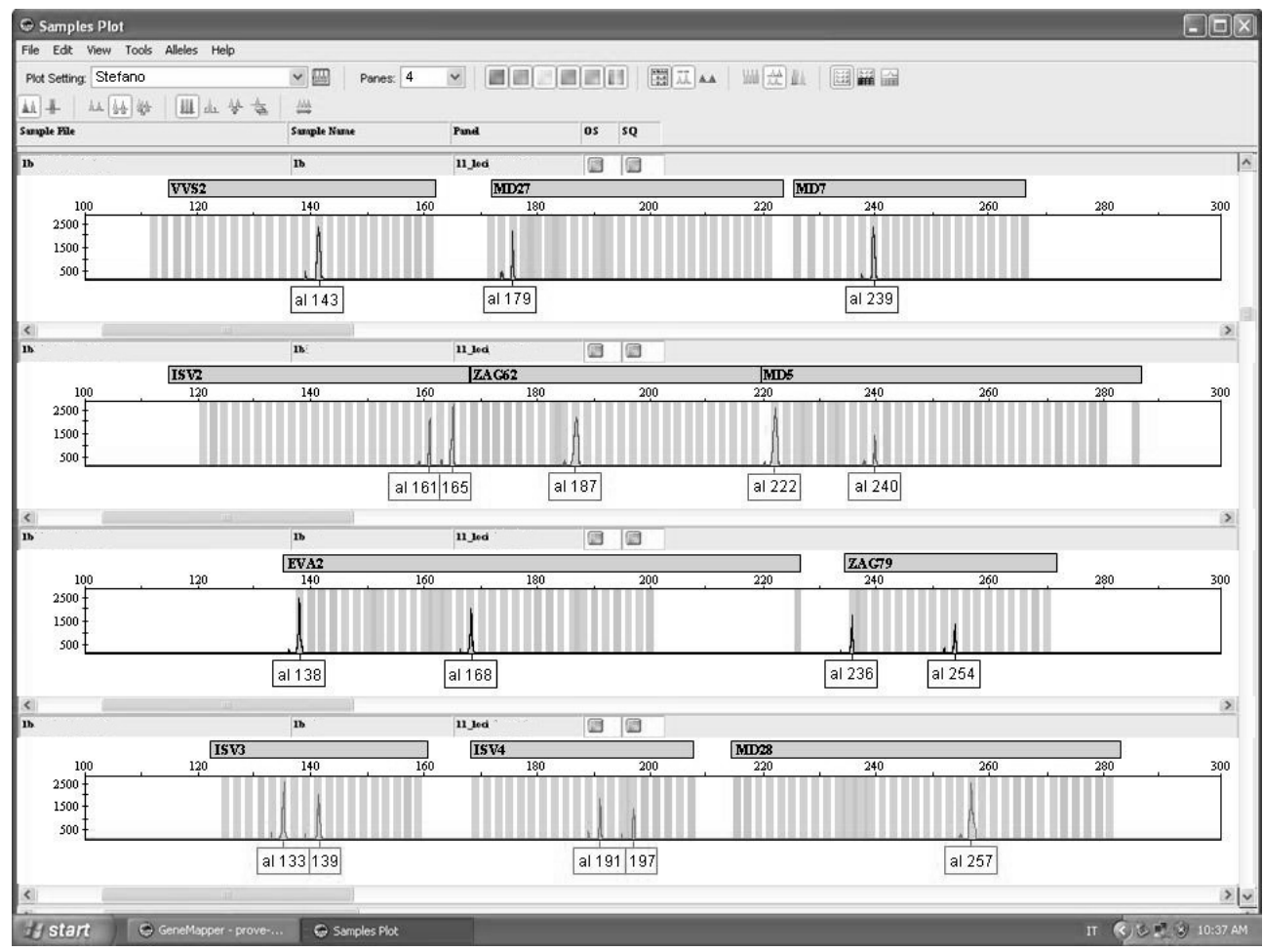

Figure 14. SSR profile at 11 loci of Istrian Malvasia cultivar by 3130XL Genetic Analyzer.

Malvasia dendrogram of morphological data in Figure 15 showed two distinct main groups: first consisted of the 22 autochthonous accessions from Croatia and second comprised the eight Italian clones.

Figure 16 reports the 16 geographic origins of the analyzed Istrian Malvasia accessions or clones. 


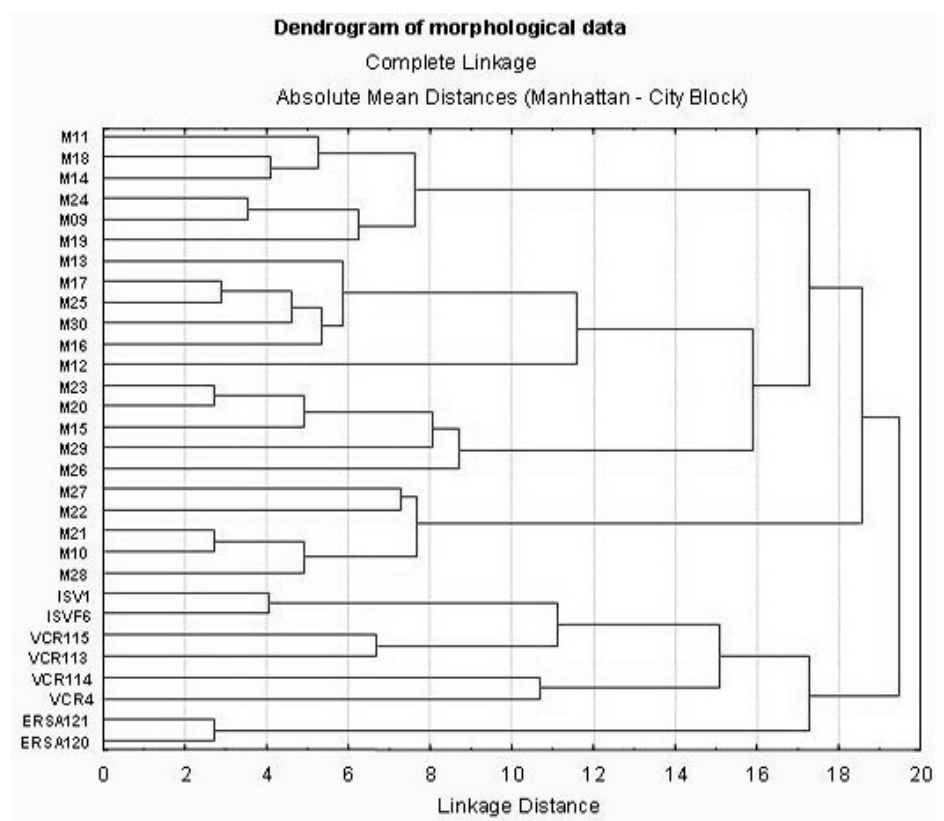

Figure 15. Dendrogram of morphological data of the 30 Istrian Malvasia accessions, of which 8 Italian clones of Istrian Malvasia (i.e., ISV 1 and ISV F6 clones, ERSA 120 and ERSA 121 clones, VCR113, VCR114, VCR115 and VCR 4 clones) and the 22 autochthonous accessions from Croatia.

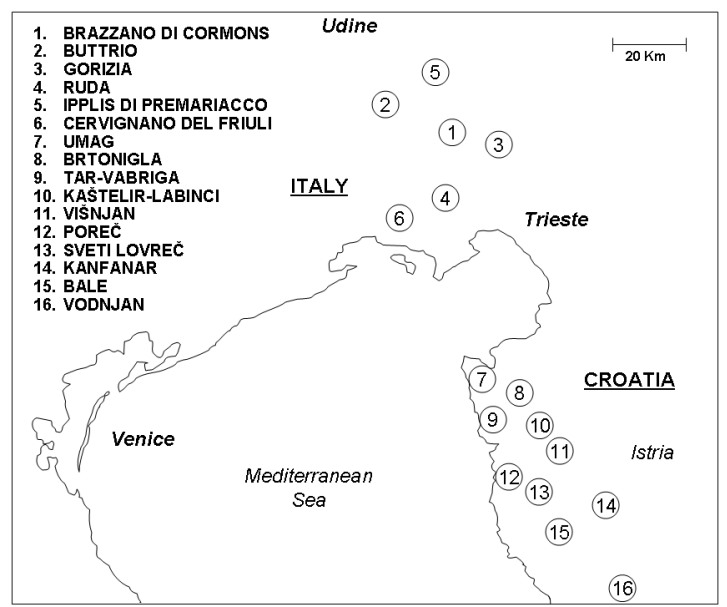

Figure 16. Geographic map of the geographic origins of the 30 Istrian Malvasia accessions from Italy (1-6) and Croatia (7-16) (Meneghetti, 2012b). 
The morphological analyses performed using the OIV ampelographic descriptors (Figure 15) discriminated the Italian clones in accordance with the three different selectors: the two clones of the ISV (i.e., ISV 1 and ISV F6), the two clones of ERSA (i.e., ERSA 120 and ERSA 121) and the four clones of VCR (i.e., VCR 113, VCR 114, VCR 115 and VCR 4). Italian clones and Croatian accessions were separated by morphological traits.

In order to study the intra-varietal genetic variability of 30 mentioned accessions AFLP, SAMPL and M-AFLP molecular analyses were performed.

A total of 1,754 reproducible amplification products were obtained (i.e., 682 DNA fragments from AFLPs, 597 DNA fragments from SAMPLs and 475 DNA fragments from M-AFLPs). Results revealed 931 (70.1\%) polymorphic molecular markers: 308 AFLPs, 302 SAMPLs and 321 M-AFLPs.

The $\mathrm{GS}_{\mathrm{TOT}}$ values of the three marker types showed that all molecular systems applied were efficient to show molecular polymorphisms between the Istrian Malvasia genotypes.

The observed $\mathrm{GS}_{\mathrm{TO}}$ was 0.8974 , the $\mathrm{GS}_{\mathrm{W}}$ within the eight Italian clones was 0.8376 and the $\mathrm{GS}_{\mathrm{W}}$ within the 22 Istrian samples was 0.9552 . This result showed that the Istrian accessions were genetically more similar to each other than the Italian clones. $\mathrm{GS}_{\mathrm{B}}$ was 0.8667 between Italian and Croatian accessions.

The $\mathrm{GS}_{\mathrm{W}}$ values were $0.9302,0.9478$ and 0.9278 within ERSA, ISV and VCR clones respectively. The $\mathrm{GS}_{\mathrm{B}}$ values were $0.8066,0.8162$ and 0.7806 between ERSA and ISV, ERSA and VCR, and ISV and VCR clones respectively.

Dice's GS matrix was used to perform the cluster analysis (Figure 17).

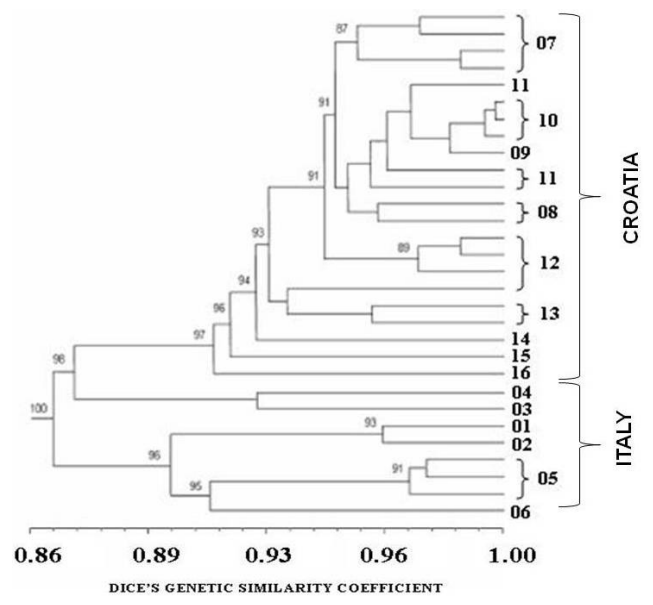

Figure 17. Dendrogram of the 30 Istrian Malvasia genotypes reveals a different molecular profile between Italian and Croatian samples. The number reported identify the different geographic origins (map of Figure 16) (Meneghetti, 2012b). 
Figure 17 reports two distinctive groups: Croatian accessions and Italian clones. Results of the AFLP, SAMPL and M-AFLP analysis did not show a complete correlation with morphological observations. In fact the dendrogram obtained by molecular data (Figure 17) was not exactly equivalent with that of morphological observations (Figure 15). However, both cluster analyses showed a clear correlation between accessions and their selectors or country.

Furthermore, the Croatian accessions were distinct in ten sub-groups in agreement with their geographic origins (i.e., 7= Umag, 8= Brtonigla, 9= Tar-Vabriga, 10= Kaštelir-Labinci, $11=$ Višnjan; $12=$ Poreč; $13=$ Sveti-Lovreč, $14=$ Kanfanar; 15= Bale, 16= Vodjan).

A similar level of distinction could be observed for the three Italian sub-groups.

We could argue that the genetic similarities are in agreement with the distance of the geographic origins.

These results suggest the need to emphasize the environmental role on the selection of genotypes during the centuries. The emphasis on preserving the autochthonous grapevine biotypes is crucial to preserve the richness of the Istrian Malvasia germplasm.

The study confirmed the importance of choosing appropriate propagation material for future cultivation in order to save the genetic variability of local biotypes. The propagation of the same clone in different territories should be also avoided in order to preserve the good interaction among genotypes and their specific environments.

Further intra-varietal studies (i.e., DNA analysis, together with ampelographic investigations), allowed the identification of Italian clones and Croatian autochthonous accessions of Istrian Malvasia.

The results have highlighted the existence of genetic variability among the Istrian Malvasia accessions from different geographical cultivation areas. These molecular approaches allowed the identification of different clones within the Istrian Malvasia cultivar and the characterization of accessions according to their geographic origins.

\section{Conclusions}

In summary, the molecular and morphological analyses showed that Vitis vinifera is a species characterized by vast genetic variability.

Molecular analyses of DNA are essential for the grapevine identification using SSR markers.

These results showed also the wide genetic variability for the grape cultivars (intra-varietal level) suggesting the need for the preservation of autochthonous grapevine biotypes found in different areas by a proper selection of the grape multiplication materials.

Infact, thisgeneticvariability accumulated during centuries of cultivationsand selections, should be both recognized and preserved, being corroborated by scientific experimental results. 
The importance of saving the genetic variability of the varieties is crucial in order to avoid to propagate the same clone in different cultivation areas.

It is highly recommended to promote the propagation of the typical autochthon biotypes, which are already wisely selected by grape vine growers.

\section{Acknowledgment}

This study is supported by both ASER and IDENTIVIT research grant from Ministero delle Politiche Agricole, Alimentari e Forestali MiPAAF, Rome, Italy.

\section{Author details}

Stefano Meneghetti ${ }^{1}$, Luigi Bavaresco ${ }^{1}$, Antonio Calò ${ }^{2}$ and Angelo Costacurta ${ }^{2}$

1 CRA-VIT Centro di Ricerca per la Viticoltura, Italy

2 AIVV Accademia italiana della Vite e del Vino, Italy

\section{References}

[1] Bavaresco, L., Giachino, E., Pezzutto, S., Fregoni, C., \& Fogher, C. (2000). PCR specific analysis of barbera clones. Bullettin de l'O.I. , 73-831, 296-311.

[2] Bowers, J. E., Dangl, G. S., \& Meredith, C. P. (1999). Development and characterization of additional microsatellite DNA markers for grape. American Journal of Enology and Viticulture, 125-130.

[3] Calò, A., Costacurta, A., Cancellier, S., \& Forti, R. (1990). Garnacha, Grenache, Cannonao, Tocai rosso, un unico vitigno. Vignevini, 9, , 45-48.

[4] Calò, A., Costacurta, A., Catalano, V., \& Di Stefano, R. (2000). Negro Amaro precoce. Rivista Viticoltura Enologia, 3, , 27-44.

[5] Calò, A., \& Costacurta, A. (2004). Dei vitigni italici. Treviso: Mattei Editor.

[6] Calò, A., Costacurta, A., Maraš, V., Meneghetti, S., \& Crespan, M. (2008). Molecular Correlation of Zinfandel (Primitivo) with Austrian, Croatian, and Hungarian Cultivars and Kratošija, an Additional Synonym. American Journal of Enology and Viticulture, 205-209.

[7] Clarke, O. (2001). Encyclopedia of grape ( Orlando: Harcourt Books., 91-100.

[8] Crespan, M., Cabello, F., Giannetto, S., Ibáňez, J., Kontić, J. K., Maletić, E., et al. (2006). Malvasia delle Lipari, Malvasia di Sardegna, Greco di Gerace, Malvasia de 
Sitges and Malvasia dubrovačka-synonyms of an old and famous grape cultivar. Vitis, 45, , 69-73.

[9] Crespan, M., Coletta, A., Crupi, P., Giannetto, S., \& Antonacci, D. (2008). Malvasia nera di Brindisi/Lecce' grapevine cultivar (Vitis vinifera L.) originated from 'Negroamaro' and 'Malvasia bianca lunga'. Vitis, 47-4, , 205 EOF-212 EOF.

[10] Cipriani, G., Spadotto, A., Jurman, I., Di Gaspero, G., Crespan, M., Meneghetti, S., Frare, E., Vignai, R., Cresti, M., Morgante, M., Pezzotti, M., Pe, E., \& Testolin, R. ((2010). ). The SSR-based profile of 1005 grapevine accessions uncovers new synonymy and parentages and reveals a large admixture among varieties of different geographic origin. TAG, 121-8: ., 1569-1585.

[11] Dangl, G. S., Mendum, M. L., Prins, B. H., Walzer, M. A., Meredith, C. P., \& Simon, C. J. (2001). Simple sequence repeat analysis of a clonally propagated species: A tool for managing a grape germplasm collection. Genome, 432-438.

[12] Dice, L. R. (1945). Measures of the amount of ecologic association between species. Ecology, 297-302.

[13] D’Onofrio, C., De Lorenzis, G., Giordani, T., Natali, L., Scalabrelli, G., \& Cavallini, A. (2009). Retrotransposon-based molecular markers in grapevine species and cultivars identification and phylogenetic analysis. Acta Horticulturae, 45-52.

[14] Fabbris, L. (1997). Statistica multivariata, analisi esplorativa dei dati. Milano: McGraw-Hill.

[15] Galet, P. (2000). Dictionnaire encyclopédique des cépages. Hachette. Paris.

[16] Galet, P. (1979). A practical ampelography: Grapevine identification. Ithaca, New York: University Press.

[17] Imazio, S., Labra, M., Grassi, F., Winfield, M., Bardini, M., \& Scienza, A. (2002). Molecular tools (SSR, AFLP, MSAP) for clone identif. ication: The case of the grapevine cultivar Traminer. Plant Breeding, 121-6, , 531-535.

[18] Labra, M., Imazio, S., Grassi, F., Rossoni, M., \& Sala, F. (2004). Vine-1 retrotransposon-based sequence-specific amplified polymorphism for Vitis vinifera L. genotyping. Plant Breeding, 180-185.

[19] Lacombe, T., Boursiquot, J. M., Laucou, V., Dechesne, F., Varès, D., \& This, P. (2007). Relationships and genetic diversity within the accessions related to Malvasia held in the Domaine de Vassal Grape germplasm repository. American Journal of Enology and Viticulture, 124-131.

[20] Levadoux, L. (1956). Les populations sauvages et cultivees de Vitis vinifera L. A. nn. Amelior Plantes, 6, , 59-118.

[21] Lynch, M. (1990). The similarity index and DNA fingerprinting. Molecular Biology and Evolution, 478-484. 
[22] Meneghetti, S., Costacurta, A., Crespan, M., Maul, E., Hack, R., \& Regner, F. (2009). Deepening inside the homonyms of Wildbacher by means of SSR markers. Vitis: 48-3, , 123-129.

[23] Meneghetti, S., Costacurta, A., Frare, E., da, Rold. G., Migliaro, D., Morreale, G., Crespan, M., Sotés, V., \& Calò, A. (2011). Clones identification and genetic characterization of Garnacha grapevine by means of different PCR-derived marker systems. Molecular Biothecnology, 48-3, , 244-254.

[24] Meneghetti, S., Costacurta, A., Morreale, G., \& Calo', A. (2012a). Study of intravarietal genetic variability in grapevine cultivars by PCR-derived molecular markers and correlations with the geographic origin. Molecular Biothecnology, 50-1: , 72-85.

[25] Meneghetti, S., Poljuha, D., Frare, E., Costacurta, A., Morreale, G., Bavaresco, L., \& Calò, A. (2012b). Inter- and intra-varietal genetic variability in Malvasia cultivars. Molecular Biothecnology, 50: , 189-199.

[26] Meneghetti, S., Bavaresco, L., \& Calò, A. (2012c). A Strategy to Investigate the Intravarietal Genetic Variability in Vitis vinifera L. for Clones and Biotypes Identification and to Correlate Molecular Profiles with Morphological Traits or Geographic Origins. Molecular Biothecnology, 52-1: , 68-81.

[27] Moreno, S., Gogorcena, Y., \& Ortiz, J. M. (1995). The use of RAPD markers for identification of cultivated grapevine (Vitis vinifera L.). Scientia Horticulturae, 237 EOF.

[28] Mullins, L. G., Bouquet, A., \& Williams, L. E. (1992). The Biology of the grapevine. Cambridge University Press. Cambridge, UK.

[29] Owens, C. L. (2003). SNP detection and genotyping in Vitis. Acta Horticulturae, 603, 139-140.

[30] Powell, W., Machray, G. C., \& Provan, J. (1996). Polymorphism revealed by simple sequence repeats. Trends in Plant Science, 215-222.

[31] Royo, J. B., Cabello, F., Miranda, S., Gogorcena, Y., González, J., Moreno, S., Itoiz, R., \& Ortiz, J. (1997). The use of isoenzymes in characterization of grapevines (Vitis vinifera L.). Influence of the environment and time of sampling. Scientia Horticulturae, 145-155.

[32] Tessier, C., David, J., This, P., Boursiquot, J. M., \& Charrier, A. (1999). Optimization of the choice of molecular markers for varietal identification in Vitis vinifera L. Theoretical and Applied Genetics, 89, , 171-177.

[33] This, P., Jung, A., Boccacci, P., Borrego, J., Botta, R., Costantini, L., et al. (2004). Development of a standard set of microsatellite reference alleles for identification of grape cultivars. Theoretical and Applied Genetics, 109, , 1448-1458. 
